\section{Floriculture Sustainability Research Coalition: Bringing the Latest Sustainability Research to the Industry}

\author{
Stephanie Burnett ${ }^{1,5}$, Neil Mattson ${ }^{2}$, Brian Krug $^{3}$, \\ and Roberto Lopez ${ }^{4}$
}

ADDITIONAL INDEX WORDs. greenhouse heating, nonchemical growth retardants, organic fertilizers

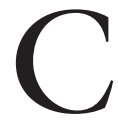
onsumer interest in environmentally friendly products has increased greenhouse growers' interest in sustainable production techniques. It is estimated that consumers would spend up to $15 \%$ more for sustainable floricultural products than conventionally produced products, and purchasers of herbaceous or floricultural plant products tend to be more eco-friendly than those who purchase woody plant materials (Behe et al., 2010; Hawkins et al., 2011). In 2008, the Floriculture Sustainability Research Coalition (FSRC) was formed to provide information regarding sustainable production techniques for growers. Forming a coalition has allowed the group to broaden our expertise to have a more meaningful impact on growers' production practices.

The FSRC began in 2008 at the National Floriculture Forum. Founding institutions include Purdue University, University of New Hampshire, Cornell University, and University of Maine. Our core purpose is to develop central sustainability themes for outreach and research programs that synergistically build on individual strengths to increase knowledge and create outreach materials that benefit our audience. Alone, it is difficult to have much of an impact on such a large topic. But, as a group, we could potentially have more impact-not only topically, but also regionally. Cornell University

\footnotetext{
This paper was part of the National Floriculture Forum, "Partnerships, Alliances, Brands and Initiatives," held 10-11 Mar. 2011 in Dallas, TX, and hosted by Texas A\&M University.

${ }^{1}$ Department of Plant, Soil, and Environmental Sciences, University of Maine, Orono, ME 04469

${ }^{2}$ Department of Horticulture, Cornell University, Ithaca, NY 14853

${ }^{3}$ University of New Hampshire Cooperative Extension, Durham, NH 03824

${ }^{4}$ Purdue University, West Lafayette, IN 47907

${ }^{5}$ Corresponding author. E-mail: sburnett@maine.edu.
}

examines sustainable and organic fertilizer use and energy conservation, Purdue University provides expertise in sustainable lighting and energy conservation, University of New Hampshire specializes in nonchemical growth regulation and sustainable fertilizer use, and at University of Maine, research focuses on water conservation and organic substrates and fertilizers.

Over the past 3 years, the FSRC has provided research-based information to help growers produce floricultural crops more sustainably. Recent initiatives have included exploring techniques for sustainably heating greenhouses, reducing plant stretch without the use of chemical growth retardants, and developing protocols for using organic fertilizers.

Conserving energy is a priority for greenhouse growers throughout the United States. A survey of greenhouse growers indicates that $55 \%$ of growers are currently using energy conservation practices; an additional $8 \%$ would like to conserve energy (Dennis et al., 2010). Our group has published several articles on novel techniques to reduce energy. For example, Lopez and Krug (2009) reported that growing medium-vigor poinsettia (Euphorbia pulcherrima) cultivars at a temperature $10^{\circ} \mathrm{F}$ less than recommended (75/ $67^{\circ} \mathrm{F}$ day/night) does not reduce crop quality for some cultivars, including 'Freedom Red'. But, this reduction in temperature set points in the fall would reduce fuel usage for greenhouse growers. At Cornell, bedding plants including 'Safari Orange' marigold (Tagetes patula), 'Delta Formula Mix' pansy (Viola Xwittrockiana), 'Dreams
Midnight' petunia (Petunia $\times$ bybrida), 'Montego Mix' snapdragon (Antirrbinum majus), and 'Dreamland Mix' zinnia (Zinnia elegans) were grown in an unheated high tunnel. Compared with the heated greenhouse environment, temperatures in the high tunnel were $5^{\circ} \mathrm{F}$ cooler (Table 1 ). Pansy plants did not finish significantly later in the high tunnel compared with the greenhouse; the other plants finished about l week later in the high tunnel. Part of our efforts in this area has focused on extension and outreach to support growers who are transitioning to more sustainable heating technologies. In trade publications, we have highlighted innovative growers who may inspire others by example (Burnett et al., 2010). Currently, Purdue University, in collaboration with Michigan State University, University of Arizona, and Rutgers University, is working on a U.S. Department of Agriculture (USDA) Specialty Crops Research Initiative grant to develop light-emitting diodes as supplemental and photoperiodic lighting for greenhouses.

Another highlight of our work with sustainable production has focused on finding alternatives to chemical growth retardants. Our approach to reducing plant stretch without chemical growth retardants has been to recommend that growers adjust the greenhouse or plant environment. $\mathrm{R}$. Lopez and B. Krug have represented our group to growers nationally and regionally. Some techniques we have successfully used include reducing water to reduce turgor in a controlled manner. Using new moisture sensors, plants may be grown in substrates that are maintained at constant moisture contents. So, they may be grown in relatively dry substrates (volumetric water content $=15 \%$ to $25 \%$ in a peatlite mix) without risking plant damage. This may reduce plant height, but controlled drought also reduces branching (Burnett and van Iersel, 2008). One straightforward way to reduce elongation is simply to grow plants at the appropriate light level. This will reduce plant stretch by minimizing shading, particularly from neighboring plants.

\begin{tabular}{llll}
\hline $\begin{array}{l}\text { Units } \\
\begin{array}{l}\text { To convert U.S. to SI, } \\
\text { multiply by }\end{array}\end{array}$ & U.S. unit & SI unit & $\begin{array}{l}\text { To convert SI to U.S., } \\
\text { multiply by }\end{array}$ \\
\hline$\left({ }^{\circ} \mathrm{F}-32\right) \div 1.8$ & ${ }^{\circ} \mathrm{F}$ & ${ }^{\circ} \mathrm{C}$ & $\left(1.8 \times{ }^{\circ} \mathrm{C}\right)+32$
\end{tabular}


Table 1. Average, minimum, and maximum temperature of a greenhouse environment (temperature set points $=70 / 60{ }^{\circ} \mathrm{F}$ day $/$ night), unheated high tunnel, and outdoor environment in Ithaca, NY, from 1 Apr. to 15 May 2010.

\begin{tabular}{lccc}
\hline & $\begin{array}{c}\text { Avg } \\
\operatorname{temp}\left({ }^{\circ} \mathbf{F}\right)^{\mathbf{z}}\end{array}$ & $\begin{array}{c}\text { Minimum } \\
\operatorname{temp}\left({ }^{\circ} \mathbf{F}\right)\end{array}$ & $\begin{array}{c}\text { Maximum } \\
\operatorname{temp}\left({ }^{\circ} \mathbf{F}\right)\end{array}$ \\
\hline Greenhouse & 66 & 55 & 89 \\
High tunnel & 61 & 30 & 107 \\
Outside & 51 & 26 & 85 \\
\hline
\end{tabular}

${ }^{z}\left({ }^{\circ} \mathrm{F}-32\right) \div 1.8={ }^{\circ} \mathrm{C}$.

Our work with organic fertilizers has provided guidance for the expanding organic greenhouse industry in the United States. Since 2004, there has been an $83 \%$ increase in the acreage of organic greenhouses (USDA, 2006). Vegetable transplants sold to consumers have become an increasingly important sector of the industry as well. In 2008, \$92 million in vegetable transplants was sold to consumers (USDA, 2009). This was a $22 \%$ increase compared with 2007. Organic growers face many challenges, but they consider managing fertility and substrates to be the greatest barrier preventing transition to organic production (Burnett and Stack, 2009).

We have published trade articles on the use of organic fertilizers and substrates (Burnett and Stack, 2009). Thus far, our collective research has indicated that liquid organic fertilizers such as Drammatic ONE (Dramm Corp., Manitowoc, WI) and Daniels ${ }^{\circledR}$ Pinnacle (Ball DP Foods, Sherman, TX) will produce high-quality crops. However, they can be 5-10 times more expensive than conventional fertilizers (N. Mattson, unpublished data). For this reason, organic growers should consider using preplant incorporated fertilizers, such as McGeary Organics (McGeary Organics, Lancaster, PA) fertilizers in addition to liquid fertilizers (G. Elliott, personal communication). Future research for our group will focus on resolving fertility issues for organic greenhouse growers. One issue they face, in addition to the cost of liquid organic fertilizers, is the lack of consistency in preplant incorporated materials. For example, plants grown in two out of four New England composts ( 1 compost:1 peat: 1 perlite) were equivalent in dry weight to those grown in substrates with a starter fertilizer (G. Hawkins and S. Burnett, unpublished data). But, compost alone does not provide adequate fertility (Bugbee and Frink, 1989; Chaney et al., 1980; Falahi-Ardakani et al., 1987), and some materials have high sodium or EC making them difficult to manage in greenhouses. Further, all organic sources of fertility release slowly, which can be challenging when managing crops with quick turnover. Our group is submitting a collaborative grant to the National Institute of Food and Agriculture, Organic Agriculture Research and Extension Initiative (NIFA-OREI) to further our research in this area.

In the future, we plan to continue our current sustainability initiatives and further help growers who wish to reduce their impact on the environment. We are also developing a website, in collaboration with OFA (The Association of Horticultural Probe a central place for posting articles and information related to sustainable greenhouse production.

\section{Literature cited}

Behe, B.K., B.L. Campbell, J.H. Dennis, C.R. Hall, R.G. Lopez, and C. Yue. 2010. Gardening consumer segments vary in ecopractices. HortScience 45:1475-1479. fessionals, Columbus, $\mathrm{OH}$ ) which will
Bugbee, G.J. and C.R. Frink. 1989. Composted waste as a peat substitute in peat-lite media. HortScience 24:625-627.

Burnett, S.E., B.A. Krug, N.S. Mattson, R.G. Lopez, and C.J. Currey. 2010. Ten ways to heat your house. Grower Talks 74:64-69.

Burnett, S.E. and M. van Iersel. 2008. Morphology and irrigation efficiency of Gaura lindhiemeri grown with capacitance sensor-controlled irrigation. HortScience 43:1555-1560.

Burnett, S. and L. Stack. 2009. Survey of the research needs of the potential organic ornamental bedding plant industry in Maine. HortTechnology 19:743-747.

Chaney, R.L., J.B. Munns, and H.M. Cathey. 1980. Effectiveness of digested sewage sludge compost in supplying nutrients for soilless potting media. J. Amer. Soc. Hort. Sci. 105:485-492.

Dennis, J.H., R.G. Lopez, B.K. Behe, C.R. Hall, C. Yue, and B.L. Campbell. 2010. Sustainable production practices adopted by greenhouse and nursery plant growers. HortScience 45:1232-1237.

Falahi-Ardakani, A., J.C. Bouwkamp, F.R. Gouin, and R.L. Chaney. 1987. Growth response and mineral uptake of vegetable transplants grown in a composted sewage sludge amended medium. I. Nutrient supplying power of the medium. J. Environ. Hort. 5:107-111.

Hawkins, G., S.E. Burnett, and L.B. Stack. 2011. Survey of consumer interest in organic, sustainable, and local bedding plants in Maine. HortTechnology (in press).

Lopez, R.G. and B.A. Krug. 2009. Cold finishing up north. Greenhouse Grower 27: 88-94.

U.S. Department of Agriculture. 2006. Data sets: Organic production. 26 Mar. 2007. <http://www.ers.usda.gov/Data/ Organic $/>$.

U.S. Department of Agriculture. 2009. 2009 Census of horticultural specialties. 25 Jan. 2011 . <http://www.agcensus. usda.gov/Publications/2007/Online_ Highlights/Census_of_Horticulture/ index.asp $>$. 